\title{
Influence of age and diet on the performance of Cephalonomia stephanoderis (Hymenoptera, Bethylidae) a parasitoid of the coffee berry borer, Hypothenemus hampei (Coleoptera, Curculionidae)
}

\author{
Jaime Gómez ${ }^{1}$, Juan F. Barrera ${ }^{1}$, Pablo Liedo ${ }^{1} \&$ Javier Valle $^{1}$
}

1El Colegio de la Frontera Sur. Apartado Postal 36, Tapachula, Chiapas, 30700, México. jgomez@ecosur.mx; jbarrera@ecosur.mx; pliedo@ecosur.mx; jvalle@ecosur.mx

\begin{abstract}
Influence of age and diet on the performance of Cephalonomia stephanoderis (Hymenoptera, Bethylidae) a parasitoid of the coffee berry borer, Hypothenemus hampei (Coleoptera, Curculionidae). The importance of age and feeding on the performance of Cephalonomia stephanoderis (Hymenoptera, Bethylidae), a parasitoid of the coffee berry borer, Hypothenemus hampei (Coleoptera, Curculionidae) was investigated in the laboratory. Groups of female parasitoids were subject to the following treatments: a group fed during one, five and ten days after emergence of adults with coffee borer larvae; another group fed only with honey solution during five days after emergence; and as a control, a third group was kept without food for five days. At the end of each treatment, survivorship, parasitoid activity (walking and flying capacity in an arena), search capacity for finding coffee borer-infested berries, host feeding and oviposition (on immature hosts), were assessed. Unfed females showed a significant decrease in survivorship compared to individuals that were fed. The type of meal (insects or honey) did not significantly influence parasitoid activity, search and oviposition capacities. Females fed with honey solution significantly consumed less immature coffee borers. Younger females (one day old) walked and flew out of the arena significantly faster than older ones ( 5 and 10 days old). Implications of these results are discussed on the performance of C. stephanoderis as a biological control agent of the coffee berry borer.
\end{abstract}

KEYWORDS. Biological control; coffee; host feeding; host searching; survivorship.

RESUMO. Influência da idade e da dieta no desempenho de Cephalonomia stephanoderis (Hymenoptera, Bethylidae) um parasitóide da broca-do-café, Hypothenemus hampei (Coleoptera, Curculionidae). A importância da idade e da alimentação no desempenho de Cephalonomia stephanoderis (Hymenoptera, Bethylidae) parasitóide da broca-do-café, Hypothenemus hampei (Coleoptera, Curculionidae) foi investigada em laboratório. Grupos de parasitóides fêmeas foram submetidos aos seguintes tratamentos: um grupo alimentado durante um, cinco e 10 dias após a emergência dos adultos sobre as larvas da broca-do-café; outro grupo foi alimentado apenas com uma solução de mel, durante cinco dias após a emergência; e como controle, um terceiro grupo foi mantido sem alimento por cinco dias. No final de cada tratamento de sobrevivência, a atividade do parasitóide (capacidade de andar e voar numa arena), a capacidade de busca (de encontrar frutos de café infestados com a broca), consumo do hospedeiro e oviposição (em hospedeiros imaturos), foram avaliados. Fêmeas em jejum mostraram uma diminuição significativa na sobrevivência de indivíduos em relação à alimentação. $\mathrm{O}$ tipo de alimento (insetos ou mel) não influenciou significativamente a atividade de busca do parasitóide e capacidades de oviposição. As fêmeas alimentadas com solução de mel consumiram significativamente menor número de imaturos da broca-do-café. Fêmeas mais jovens (um dia) andaram e voaram da arena significativamente mais rápido que as mais velhas (5 e 10 dias de idade). Implicações desses resultados são discutidas sobre o desempenho de C. stephanoderis como um agente de controle biológico da broca-do-café.

PALAVRAS-CHAVE. Café; consumo alimentar; controle biológico; localização do hospedeiro; sobrevivência.

The coffee berry borer (CBB), Hypothenemus hampei (Ferrari) (Coleoptera, Curculionidae), is the most important insect pest for coffee growers in tropical America. This species spends most of its life feeding inside the coffee berries, affecting the quantity and quality of coffee. Cephalonomia stephanoderis Betrem (Hymenoptera, Bethylidae) is an African parasitoid that has been introduced in several Latin American and Caribbean countries during the past 20 years for biological control of H. hampei (Barrera et al. 1990a, 1990b; Murphy \& Moore 1990; Baker 1999). C. stephanoderis is a solitary ectoparasitoid that attacks eggs, larvae, prepupae and pupae of $H$. hampei. Female parasitoid enters into the infested fruit through the CBB entrance hole and if there is enough host population, it establishes there permanently. The female parasitoid feeds on all developing stages of the coffee borer and starts parasitizing prepupae or pupae only until it has developed mature eggs. After the onset of the oviposition period, parental females remain with their broods until completion of offspring development. Young C. stephanoderis females disperse after mating and search for new hosts to repeat the cycle. It is assumed that females can feed on sugary substances if the searching period is prolonged. It takes from 16 to 20 days at $27^{\circ} \mathrm{C}$ for the parasitoid to develop from egg to adult. Female parasitoids live longer than males, and oviposit an average of 66 eggs during a lifetime of 80 days (Barrera et al. 1989, 1993; Abraham et al. 1990; Lauzière et al. 2001).

Several field studies have been performed to assess the impact of inoculative and inundative releases of $C$. stephanoderis 
on H. hampei. The parasitism of C. stephanoderis ranged from 0-65\% after release (Benavides et al. 1994; Quintero et al. 1998; Baker 1999; Damon \& Valle 2002). It is well known that the efficacy of natural enemies as biological control agents can be affected by several intrinsic factors such as, mating, aging, feeding and experience (Godfray 1994; Quicke 1997; Wyatt 1997). Particularly, insect diet and aging can modify female foraging strategies.

Regarding insect diet, several studies showed that female parasitoids spend several days feeding on non-host foods such as honeydew, pollen, nectar and other plant exudates during early adult life and start host-feeding only when the development of the ovaries is sufficiently advanced (Jervis \& Kidd 1986). In Aphytis melinus DeBach (Hymenoptera, Aphelinidae), host feeding prolongs life in the presence of honey (Heimpel \& Collier 1996). Takasu \& Lewis (1995) found that Microplitis croceipes (Cresson) (Hymenoptera, Braconidae) females which were well-fed prior to release parasitized more hosts than unfed females. Practitioners of classical biological control have argued that parasitoids should have a ready supply of non-host foods in areas where they are released, in order to increase the chances of the biological agents becoming established (Jervis et al. 1996).

With respect to aging, Heimpel \& Collier (1996) indicated that parasitoid age can affect host-feeding strategies in two ways: first, characteristics of nutrient allocation early in the parasitoid's life can affect temporal patterns of host use; and second, parasitoid age can affect host-feeding strategies through its effect on life expectancy. Those findings suggest that it is possible to manipulate the parasitoid's hunger state and parasitoid age as a tool for parasitoid release programs.

The objective of this study was to investigate the influence of age and diet of female $C$. stephanoderis on its performance. This effect was measured on the survival, parasitoid activity, searching capacity, host consumption and fecundity of $C$. stephanoderis females. This information might be useful to explain and understand the variability of the parasitism of this species under field conditions.

\section{MATERIAL AND METHODS}

All the experiments used the same batch of parasitoids in a continuous manner. Laboratory conditions were $27 \pm 2^{\circ} \mathrm{C}$, $65-85 \%$ RH and a photoperiod of 12:12 hours.

Insects. Specimens of $C$. stephanoderis were reared in the laboratory from wild populations collected in the previous year in a coffee plantation at the Soconusco region in Chiapas, Mexico. Parasitoids were reared following the procedures described elsewhere (Barrera et al. 1989).

At emergence, females were grouped and isolated to obtain equal-age cohorts. Groups of five to ten females were placed in $5.0 \mathrm{~cm}$ Petri dishes and every three days were offered 30 to 60 immature stages (eggs, larvae, prepupae and pupae) of $H$. hampei as a diet. Individuals that were parasitized by $C$. stephanoderis were separated daily and placed inside $7.0 \mathrm{~cm}$ height and $1.7 \mathrm{~cm}$ diameter flat-bottom glass tubes, until adult emergence as described by Barrera et al. (1993). These individuals of known age were used to determine age and diet effects on their performance, following an experimental protocol that was divided in two parts, as follows.

Experimental protocol: first part. A total of 330 specimens of C. stephanoderis newly-emerged females of the same age were subjected to five treatments. To determine the effect of the age, three different groups of these females were fed on immature stages of $\mathrm{CBB}$ for one (CBB1), five (CBB5) and ten days (CBB10). Two additional groups of females of five days old were included: a group fed with water solution of honey (1:1) (HB5) and a group of unfed females (U5). Five days old females were used for the tests because their longevity is approximately one week without food. To determine the effect of diet, these two groups (HB5 and U5) were compared with the group fed on immature borers during five days (CBB5). Groups of ten insects were kept inside the glass tubes for the time periods mentioned for every treatment. The experiment was repeated three times. In order to induce mating, two males were kept in the tubes during the first $48 \mathrm{~h}$ after the experiment was initiated, except for the treatment CBB1, in which males and females were kept together for $24 \mathrm{~h}$ only.

At the end of every feeding period considered in each treatment, we recorded the total number of live and dead females, and with these data we calculated the survivorship. Treatment effect over survivorship was analyzed with a maximum likelihood test $\chi^{2}(\mathrm{G})$ with a $\mathrm{P}<0.05$ (Zar 1996) and correspondence analysis was done (Everitt \& Dunn 1991). In the cases where significant differences among treatments were found, age (CBB1, CBB5 and CBB10) and diet (CBB5, HB5 and U5) effects were analyzed separately applying Bonferroni $(\mathrm{P}<0.025)$ correction for an error type I (Scheiner 2001).

Experimental protocol: second part. C. stephanoderis females that survived to the feeding treatment were randomly chosen and grouped in three sets or replicates with ten individuals each, and a total of 30 females per treatment. These insects were submitted to the following three assays:

Parasitoid activity. Each one of the ten selected females was placed at the center of the arena $(20 \mathrm{~cm}$ diameter with white paper on the bottom) recording the time required (in seconds) to leave the arena (walking or flying). Mean times for leaving the arena were transformed to $\ln (\mathrm{x})$ and analyzed by one-way ANOVA. Means were compared by Tukey's test at $5 \%$. The number of females that left the arena per treatment was analyzed, using a Maximum likelihood test $\chi^{2}(\mathrm{G})$ with a $\mathrm{P}<0.05$ (Zar 1996) and Correspondence analysis was done to graphically find associations among treatments (Everitt \& Dunn 1991). In cases where significant differences among treatments were found, age (CBB1, CBB5 and CBB10) and feeding (CBB5, HB5 and U5) effects were analyzed separately, using Bonferroni $(\mathrm{P}<0.025)$ correction to minimize the error type I (Scheiner 2001).

Searching capacity. At the end of the activity of the parasitoids, groups of ten C. stephanoderis per treatment were 
placed inside a plastic container $(15 \mathrm{~cm}$ height and $25 \mathrm{~cm}$ diameter) with both ends covered with fine mesh. Twenty red coffee beans from the field containing all life stages of the coffee berry borer (Barrera et al. 1992; Gómez 1994) were placed inside the cylindrical container before experiments. The number of parasitoids entering into the beans were recorded every $120 \mathrm{~min}$ for a period of $8 \mathrm{~h}$. After $24 \mathrm{~h}$, a final observation was made and immediately the fruits were dissected to recover the parasitoids, which were used in the next assay. The number of parasitoids entering the fruits in each treatment was analyzed using a repeated measures analysis of variance.

Host feeding and oviposition. The females of $C$. stephanoderis recovered from the previous assay (those that entered the beans and those that did not) were individually placed in flat-bottom tubes with 20 immature stages of $H$. hampei (five of each, eggs, larvae, prepupae and pupae). Three replicates were performed with ten females per treatment. Host consumption by $C$. stephanoderis on eggs, larvae, prepupae and pupae, as well as the numbers of parasitized prepupae and pupae were recorded at 4, 8 and 12 days. Mean numbers of consumed and parasitized immature individuals at each period were analyzed by repeated measures ANOVA (Quinn \& Keough 2002). When statistical differences were significant, means were compared by Tukey's test at $5 \%$. In those cases where significant differences among treatments were found, age (CBB1, CBB5 and CBB10) and feeding (CBB5, HB5 and U5) effects were analyzed separately using Bonferroni $(\mathrm{P}<0.025)$ correction to minimize the error type I (Scheiner 2001).

\section{RESULTS}

Survivorship. The effects on survivorship by age and diet on C. stephanoderis females are shown on Table I. Survivorship ranged from 86.5 to $100 \%$ and significant differences among treatments were observed $\left(\chi^{2}=22.73\right.$, df $=4$; $\mathrm{P}<0.05$ ). The U5 treatment (unfed for five days) had the highest mortality (13.5\%). In order to separate age from diet effects, a $\mathrm{G}$ test with a Bonferroni correction was applied, showing no significant differences related to age (CBB1, CBB5, CBB10) $\left(\chi^{2}=3.88, \mathrm{df}=2 ; \mathrm{P}=0.14\right)$, but significance related to the type of $\operatorname{diet}(\mathrm{CBB} 5, \mathrm{HB} 5, \mathrm{U} 5)\left(\chi^{2}=14.95\right.$,

Table I. Survivorship of Cephalonomia stephanoderis females considering five diet and age treatments.

\begin{tabular}{|c|c|c|c|c|}
\hline \multicolumn{2}{|r|}{ Treatments } & \multicolumn{2}{|c|}{ Number of live females } & \multirow{2}{*}{$\begin{array}{l}\text { Survivorship } \\
\text { (\%) }\end{array}$} \\
\hline Age (days) & Diet & Initial & Final & \\
\hline 1 & Immature coffee berry borers & 57 & 57 & $100.0 \mathrm{a}$ \\
\hline 5 & Immature coffee berry borers & 66 & 66 & $100.0 \mathrm{a}$ \\
\hline 10 & Immature coffee berry borers & 60 & 58 & $96.7 \mathrm{a}$ \\
\hline 5 & Honey & 58 & 56 & $96.5 \mathrm{a}$ \\
\hline 5 & No food & 89 & 77 & $86.5 \mathrm{~b}$ \\
\hline
\end{tabular}

Values followed by different letters indicate significant differences in the column (G test, followed by Correspondence analysis, $\mathrm{P}<0.05$ ). $\mathrm{df}=2 ; \mathrm{P}=0.0006)$. These findings confirm that lack of food during five days (U5) decreases parasitoid survivorship to $86.5 \%$ in comparison with those insects fed with diluted honey or with immature stages of H. hampei, where survivorship was greater than $96 \%$.

Parasitoid activity. All insects left the arena in 11.0 to 185.0 s. (Table II). ANOVA analysis showed significant differences among treatment means $(\mathrm{F}=6.27 ; \mathrm{df}=4,10 ; \mathrm{P}=0.008)$. Females from U5 significantly required more time $(44.5 \pm 7.21 \mathrm{~s})$ to leave the arena than those from CBB1 $(16.3 \pm 1.79 \mathrm{~s})$ (Fig. 1).

Table II. Average time taken by female Cephalonomia stephanoderis to leave the experimental arena $(20 \mathrm{~cm}$ in diameter). Parasitoids were submitted to five treatments where diet and age were manipulated.

\begin{tabular}{|c|c|c|}
\hline \multicolumn{2}{|r|}{ Treatments } & \multirow{2}{*}{$\begin{array}{l}\text { Mean time (sec) } \\
(\overline{\mathrm{x}} \pm \mathrm{SE})\end{array}$} \\
\hline Age (days) & Diet & \\
\hline 1 & Immature coffee berry borers & $16.3 \pm 1.79 \mathrm{a}$ \\
\hline 5 & Immature coffee berry borers & $28.0 \pm 3.17 \mathrm{ab}$ \\
\hline 10 & Immature coffee berry borers & $30.0 \pm 1.71 \mathrm{ab}$ \\
\hline 5 & Honey & $26.7 \pm 3.03 \mathrm{ab}$ \\
\hline 5 & No food & $44.5 \pm 7.21 \mathrm{~b}$ \\
\hline
\end{tabular}

Values followed by different letters indicate significant differences in the column $(\mathrm{G}$ test, followed by Correspondence analysis, $\mathrm{P}<0.05$ ).

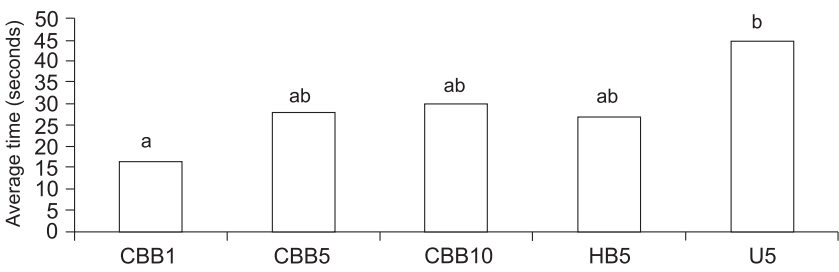

Fig. 1. Average time taken by Cephalonomia stephanoderis females to leave the experimental arena $(20 \mathrm{~cm}$ in diameter). Parasitoids come from five treatments where diet and age were manipulated. CBB1 $=$ Fed with immature coffee berry borer for one day; $\mathrm{CBB} 5=$ Fed with immature coffee berry bore for five days; $\mathrm{CBB} 10=$ Fed with immature coffee berry borer for ten days; HB5 = Fed with a water solution of honey for five days; U5 = Unfed for five days. Values followed by different letters indicate significant differences between treatments (ANOVA, followed by Tukey's test, $\mathrm{P}$ $<0.05)$.

Significant differences were found regarding age $(\mathrm{F}=$ $17.63 ; \mathrm{df}=2,6 ; \mathrm{P}=0.003)$, but not for diet's type $(\mathrm{F}=2.63$; $\mathrm{df}=2,6 ; \mathrm{P}=0.15$ ). It was clear that younger females (one day old) left the arena faster than the older ones (five to ten days old).

Significant differences were found when comparing type of displacement, walking or flying ( $\mathrm{G}$ test, $\chi^{2}=28.06$, $\mathrm{df}=$ 4; $\mathrm{P}<0.05$ ) (Table III). Results from the correspondence graphic analysis showed that the number of individuals flying from the arena was higher when females were fed for one day with immature stages (CBB1) compared with those of the other treatments.

Bonferroni's test, applied to analyze age and diet effects, showed significant differences for age (CBB1, CBB5, 
CBB10) $\left(\chi^{2}=20.94\right.$, df $\left.=2 ; \mathrm{P}<0.025\right)$, but not for diet $(\mathrm{CBB} 5, \mathrm{HB} 5, \mathrm{U} 5)\left(\chi^{2}=1.73, \mathrm{df}=2 ; \mathrm{P}=0.421\right)$. These results demonstrated that a larger number (nine) of young females (CBB1, 1 day old) left the arena flaying compared with older females, in which only one female (HB5, five days old) flew out (Table III)

Table III. Number of Cephalonomia stephanoderis females that left, running or walking, the experimental arena $(20 \mathrm{~cm}$ in diameter). Parasitoids were submitted to five treatments where diet and age were manipulated.

\begin{tabular}{clcccc}
\hline & \multicolumn{2}{c}{ Treatments } & \multicolumn{2}{c}{ Number of females } & $\begin{array}{c}\text { Correspondence } \\
\text { analysis }\end{array}$ \\
\cline { 1 - 1 } \cline { 5 - 6 } Age (days) & \multicolumn{1}{c}{ Diet } & & Walking & Flying & \\
\cline { 1 - 1 } 5 & Immature coffee berry borers & 21 & 9 & $\mathrm{a}$ \\
10 & Immature coffee berry borers & 30 & 0 & $\mathrm{~b}$ \\
5 & Immature coffee berry borers & 30 & 0 & $\mathrm{~b}$ \\
5 & Honey & 29 & 1 & $\mathrm{~b}$ \\
& No food & 30 & 0 & $\mathrm{~b}$ \\
\hline
\end{tabular}

Values followed by different letters indicate significant differences in the column $(\mathrm{G}$ test, followed by Correspondence analysis, $\mathrm{P}<0.05$ ).

Searching capacity. The number of $C$. stephanoderis females per treatment that found and enter $H$. hampei-infested coffee beans at different times is shown on Table IV. There were not significant differences among the five treatment $(\mathrm{F}=3.28$; $\mathrm{df}=4,10 ; \mathrm{P}=0.058)$, nor treatments interactions due to time $(\mathrm{F}=1.078 ; \mathrm{df}=16 ; \mathrm{P}=0.406)$, but there were significant differences regarding observation time $(\mathrm{F}=10.97 ; \mathrm{df}=4,40 ; \mathrm{P}<$ $0.05)$. The number of parasitoids that found and entered the fruits, increased as time passed by, fewer individuals found and enter the fruit after $2 \mathrm{~h}(5.60 \pm 0.60)$ than at $24 \mathrm{~h}(8.40 \pm 0.43)$.

Host feeding and oviposition. Table $\mathrm{V}$ shows consumption by females of $C$. stephanoderis. There was a significant difference among treatments $(F=5.303 ; \mathrm{df}=4,10 ; \mathrm{P}=0.015)$. The number of immature insects consumed by HB5 (females fed with honey during five days) was significantly lower than those from CBB5, CBB10 and U5, but similar to CBB1 (Table $\mathrm{V})$. When comparing feeding and age effects with Bonferroni's test, no significant difference was found for age $(\mathrm{F}=0.386$; $\mathrm{df}$ $=2,6 ; \mathrm{P}=0.696)$, but a significant difference was detected for $\operatorname{diet}(\mathrm{F}=7.694 ; \mathrm{df}=2,6 ; \mathrm{P}=0.022)$. Data analysis considering periods of three days showed that parasitoids could attack a larger number of prey during the first period than in the subsequent two periods $(\mathrm{F}=8.958 ; \mathrm{df}=2,20 ; \mathrm{P}=0.002)$ (Table $\mathrm{V})$.
Table V. Average number of immature stages (eggs, larvae, prepupae and pupae) of Hypothenemus hampei consumed by Cephalonomia stephanoderis females. Parasitoids were submitted to five treatments where diet and age were manipulated.

\begin{tabular}{clccccc}
\hline & \multicolumn{2}{c}{ Treatments } & & \multicolumn{3}{c}{ Observation periods (days) } \\
\cline { 1 - 3 } \cline { 5 - 7 } Age (days) & \multicolumn{1}{c}{ Diet } & & $1-4$ & $5-8$ & $9-12$ & $\overline{\mathrm{x}} \pm \mathrm{SE}$ \\
\hline 1 & Immature coffee berry borers & & 2.51 & 2.35 & 2.46 & $2.44 \pm 0.07 \mathrm{ab}$ \\
5 & Immature coffee berry borers & & 2.52 & 2.54 & 2.56 & $2.54 \pm 0.05 \mathrm{~b}$ \\
10 & Immature coffee berry borers & & 2.97 & 2.30 & 2.39 & $2.56 \pm 0.08 \mathrm{~b}$ \\
5 & Honey & & 2.11 & 1.63 & 1.70 & $1.81 \pm 0.06 \mathrm{a}$ \\
5 & No food & 3.07 & 2.32 & 2.29 & $2.56 \pm 0.11 \mathrm{~b}$ \\
\hline
\end{tabular}

Values followed by different letters indicate significant differences in the column (ANOVA, followed by Tukey's test, $\mathrm{P}<0.05$ ).

No significant differences were detected for prepupae and pupae consumption by $C$. stephanoderis $(\mathrm{F}=1.25$; $\mathrm{df}=4$, $10 ; \mathrm{P}=0.349$ ) (Table VI). However, a significant difference was detected for observation periods $(\mathrm{F}=4.495 ; \mathrm{df}=2,20$; $\mathrm{P}=0.024)$, since parasitoids ate more prepupae and pupae in the last period (9 to 12 days).

Table VI. Average number of prepupae and pupae of Hypothenemus hampei daily parasitized by Cephalonomia stephanoderis females. Parasitoids were submitted to five treatments where diet and age were manipulated.

\begin{tabular}{|c|c|c|c|c|c|}
\hline \multicolumn{2}{|r|}{ Treatments } & \multicolumn{4}{|c|}{ Observation periods (days) } \\
\hline Age (days) & Diet & $1-4$ & $5-8$ & $9-12$ & $\bar{x} \pm S E$ \\
\hline 1 & Immature coffee berry borers & 0.19 & 0.36 & 0.49 & $0.34 \pm 0.03 \mathrm{a}$ \\
\hline 5 & Immature coffee berry borers & 0.33 & 0.49 & 0.56 & $0.46 \pm 0.03 \mathrm{a}$ \\
\hline 10 & Immature coffee berry borers & 0.46 & 0.36 & 0.54 & $0.45 \pm 0.03 \mathrm{a}$ \\
\hline 5 & Honey & 0.49 & 0.30 & 0.44 & $0.41 \pm 0.02 \mathrm{a}$ \\
\hline 5 & No food & 0.63 & 0.38 & 0.52 & $0.51 \pm 0.05 \mathrm{a}$ \\
\hline
\end{tabular}

Values followed by different letters indicate significant differences in the column (ANOVA, $\mathrm{P}<0.05$ ).

Table VII shows data on oviposition during the three observation periods. There were no significant differences among treatments $(\mathrm{F}=1.651 ; \mathrm{df}=4,10 ; \mathrm{P}=0.237)$. However, when observation periods were compared, significant differences were found $(\mathrm{F}=21.763 ; \mathrm{df}=2,20 ; \mathrm{P}<0.05)$. Females oviposited more eggs during the intermediate period (5 to 8 days).

Table IV. Average number of Cephalonomia stephanoderis females that enter infested coffee beans. Parasitoids were submitted to five treatments where diet and age were manipulated.

\begin{tabular}{|c|c|c|c|c|c|c|c|}
\hline \multicolumn{2}{|r|}{ Treatments } & \multicolumn{6}{|c|}{ Time of observation (h) } \\
\hline Age (days) & Diet & 2 & 4 & 6 & 8 & 24 & $\overline{\mathrm{x}} \pm \mathrm{SE}$ \\
\hline 1 & Immature coffee berry borers & 8.33 & 8.33 & 8.67 & 8.67 & 9.33 & $8.67 \pm 0.37 \mathrm{a}$ \\
\hline 5 & Immature coffee berry borers & 5.33 & 6.67 & 7.33 & 7.33 & 9.33 & $7.20 \pm 0.47 \mathrm{a}$ \\
\hline 10 & Immature coffee berry borers & 6.33 & 6.67 & 8.33 & 8.33 & 9.33 & $7.80 \pm 0.49 a$ \\
\hline 5 & Honey & 3.67 & 7.00 & 7.33 & 8.00 & 7.67 & $6.73 \pm 0.47 \mathrm{a}$ \\
\hline 5 & No food & 4.33 & 6.00 & 5.33 & 6.67 & 6.33 & $5.73 \pm 0.42 \mathrm{a}$ \\
\hline
\end{tabular}

Values followed by different letters indicate significant differences in the column (ANOVA, $\mathrm{P}<0.05$ ). 
Table VII. Average number of daily oviposition by Cephalonomia stephanoderis females. Parasitoids were submitted to five treatments where diet and age were manipulated.

\begin{tabular}{clccccc}
\hline & \multicolumn{2}{c}{ Treatments } & & \multicolumn{3}{c}{ Observation periods (days) } \\
\cline { 1 - 4 } \cline { 5 - 7 } Age (days) & \multicolumn{1}{c}{ Diet } & & $1-4$ & $5-8$ & $9-12$ & $\overline{\mathrm{x}} \pm \mathrm{E}$ \\
\hline 1 & Immature coffee berry borers & & 0.93 & 1.65 & 1.46 & $1.35 \pm 0.12 \mathrm{a}$ \\
5 & Immature coffee berry borers & & 0.96 & 1.17 & 0.85 & $0.99 \pm 0.05 \mathrm{a}$ \\
10 & Immature coffee berry borers & 0.99 & 1.41 & 1.10 & $1.17 \pm 0.10 \mathrm{a}$ \\
5 & Honey & & 0.43 & 1.05 & 0.86 & $0.78 \pm 0.05 \mathrm{a}$ \\
5 & No food & 1.04 & 1.28 & 1.15 & $1.15 \pm 0.09 \mathrm{a}$ \\
\hline
\end{tabular}

Values followed by different letters indicate significant differences in the column (ANOVA, $\mathrm{P}<0.05$ )

\section{DISCUSSION}

Influence of diet and age on longevity of adult parasitoids has been investigated in many laboratory studies; however, the novel aspect of our study was to determine diet and age effects on parasitoid's performance and several other biological parameters. Our study demonstrated that after emergence, some biological attributes of $C$. stephanoderis females were affected by age and diet, particularly survivorship, host feeding and flying activity; however, searching capacity and oviposition were not affected.

It is well known that feeding can affect longevity of adult parasitoids (Jervis \& Kidd 1986). Laboratory studies have demonstrated that parasitoids fed with honey or sugary solutions have their longevity and/or fecundity increased (Syme 1977; Hagley \& Barber 1992; Leatemia et al. 1995; Siekmann et al. 2001; Sisterson \& Averill 2002). In the case of C. stephanoderis, laboratory studies demonstrated that diluted honey extends adult survivorship up to 80\% (Abraham et al. 1990; Barrera et al. 1993; Lauzière et al. 2000). Our results confirm this observations and clearly establishes that survivorship of honey-deprived insects is severely decreased, since none of them last more than eight days. These results support the recommendation that $C$. stephanoderis adults have to be honey fed before they are released in the field (Barrera et al. 1993).

Some studies indicate that longevity increases when the female feeds on its host, and it is even better than sugar or honey solution intake (Leius 1961; Jervis \& Kidd 1986; Collier 1995). In the case of $C$. stephanoderis, host feeding considerably increased female longevity, when they fed on immature stages of CBB for more than one month, than when fed with honey (Lauzière et al. 2000). Nevertheless, in shorter periods, there are no significant differences in survivorship between insects fed with the two types of diet. Our results showed that survivorship in parasitoids fed with honey or with immature $\mathrm{CBB}$ was greater than $96 \%$.

Intake of honey or immature $\mathrm{CBB}$ also did not influence walk or flight capacity. The time to leave and take off from the experimental arena was not significantly different between the groups, even for unfed females. However, walk and flight activities were significantly affected by age. One day old females took shorter time to leave the arena and a larger percentage of them escaped flying, compared to five and ten-day old females. Our results suggest that age could be an important factor in $C$. stephanoderis dispersion, which occurs as soon as the insect is released in the field. This was observed also by King (1993) for Nasonia vitripennis (Walker) (Hymenoptera, Pteromalidae) and by Nurindah et al. (1999) for Trichogramma australicum Girault (Hymenoptera, Trichogrammatidae).

Searching capacity can also be affected by food deprivation and consequently it can affect performance (Lewis et al. 1998). However, in this study, feeding did not influence significantly searching capacity, since we observed that more that $50 \%$ of $C$. stephanoderis females entered the infested coffee beans in the $24 \mathrm{~h}$, despite of being fed or not. Those unfed females that did not enter the beans before $24 \mathrm{~h}$ presented up to $20 \%$ mortality, compared to those fed. For another parasitoid, Phanerotoma franklini Gahan (Hymenoptera, Braconidae), Sisterson \& Averill (2002) found that foraging capacity in unfed females was affected, since they presented a high mortality rate.

We found C. stephanoderis females fed with honey prior to the experiments consumed less eggs and larvae of hosts than females feeding on immature stages or unfed females. However, no differences for the parasitism of prepupae and pupae were found between treatments. This result is interesting because according to Heimpel \& Rosenheim (1995), a honey fed female will consume a smaller number of immature hosts and consequently there would be an increase in their reproductive success, since this will allow larvae development that could be used for oviposition. Reasons to explain these results are not very clear, we believe that female parasitoids that fed on honey were satiated and as a consequence they change their feeding behavior consuming less eggs and larvae (Jácome et al. 1999). Other possibility is that honey in combination with the protein of prepupae and pupae was enough to supply the nutritional requirements of the parasitoid (Jervis \& Kidd 1986). It could reduce egg consumption, but can result in similar oviposition rates than females that fed on CBB immature stages only. Another plausible explanation is that $C$. stephanoderis feeding on its host is a facultative strategy conditioned to the availability of other type of food (Heimpel \& Collier 1996).

Based on our results, we conclude that honey intake is important for $C$. stephanoderis adults' performance before they are released in the field because it is a food supplement that increases longevity and survivorship. Feeding parasitoids with honey before release is especially important when hosts are scarce and parasitoids have to explore large areas of habitat for long periods. Age, however, seems to be a factor of more consideration, since our data suggest that it affects activities and searching capacity of the parasitoids. This information is fundamental to improve parasitoid biological control programs against the coffee berry borer.

\section{ACKNOWLEDGMENTS}

We thank Francisco Infante and Julio Rojas for comments on an earlier draft of this manuscript. Jaime Gómez received a doctoral grant from CONACyT. 


\section{REFERENCES}

Abraham, Y. J.; D. Moore \& G. Godwin. 1990. Rearing and aspects of biology of Cephalonomia stephanoderis and Prorops nasuta (Hymenoptera: Bethylidae) parasitoids of the coffee berry borer, Hypothenemus hampei (Coleoptera: Scolytidae). Bulletin of Entomological Research 80: 121-128.

Baker, P. S. 1999. Colombian coffee IPM. Biocontrol News and Information 20: 72-73.

Barrera, J. F.; J. Gómez; F. Infante; A. Castillo \& W. de la Rosa. 1989. Biologie de Cephalonomia stephanoderis Betrem (Hymenoptera: Bethylidae) en laboratoire. I. Cycle biologique, capacité d'oviposition et émergence du fruit du caféier. Café, Cacao, Thé 33: 101-108.

Barrera, J. F.; P. S. Baker; J. E. Valenzuela \& A. Schwarz. 1990a. Introducción de dos especies de parasitoides africanos a México para el control biológico de la broca del café, Hypothenemus hampei (Ferrari) (Coleoptera: Scolytidae). Folia Entomológica Mexicana 79: 245-247.

Barrera, J. F.; F. Infante; M. Vega; O. González; E. Carrillo; O. Campos; R. Muñóz; A. Serrano; J. J. Osorto; B. Decazy \& D. Moore. 1990b. Introducción de Cephalonomia stephanoderis (Hymenoptera: Bethylidae) a Centroamérica para el control biológico de la broca del cafeto, Hypothenemus hampei (Coleptera: Scolytidae). Turrialba 40: 570-574.

Barrera, J. F.; F. Infante; J. Gómez; A. Castillo \& W. De La Rosa. 1992. Cría y manejo de parasitoides para el control biológico de la broca del café en comunidades rurales. Guía Práctica. CIES-SDRyE, 31 p.

Barrera, J. F.; F. Infante; C. Alauzet; J. Gómez; W. de la Rosa \& A. Castillo. 1993. Biologie de Cephalonomia stephanoderis Betrem (Hymenoptera: Bethylidae) en laboratoire. II. Durée de développement, sex-ratio, longévité et espérance de vie des adultes. Café, Cacao, Thé 37: 205-214.

Benavides, P.; A. E. Bustillo \& E. C. Montoya. 1994. Avances sobre el uso del parasitoide Cephalonomia stephanoderis para el control de la broca del café, Hypothenemus hampei. Revista Colombiana de Entomología 20: 247-253.

Collier, T. R. 1995. Host feeding, egg maturation, resorption and longevity in the parasitoid Aphytis melinus (Hymenoptera: Aphelinidae). Annals of the Entomological Society of America 88: 206-214.

Damon, A. \& J. Valle. 2002. Comparison of two release techniques for the use of Cephalonomia stephanoderis (Hymenoptera: Bethylidae), to control the coffee berry borer Hypothenemus hampei (Coleoptera: Scolytidae) in Soconusco, southeastern México. Biological Control 24: 117-127.

Everitt, B. S. \& G. Dunn. 1991. Applied multivariate data analysis. Cambridge, Edward Arnold, 304 p.

Godfray, H. C. J. 1994. Parasitoids: behavioral and evolutionary ecology. New Jersey, Princeton University Press, Princeton, 488 p.

Gómez-Ruiz, J. 1994. Biología y propagación en laboratorio de la broca del café (Hypothenemus hampei) (Ferrari) (Coleoptera: Scolytidae) y su parasitoide Cephalonomia stephanoderis Betrem (Hymenopera: Bethylidae). Tese de Licenciatura, Universidad Nacional Autónoma de México, 79 p.

Hagley, E. A. C. \& D. R. Barber. 1992. Effect of food sources on the longevity and fecundity of Pholetesor ornigis (Weed) (Hymenoptera: Braconidae). The Canadian Entomologist 124: 341-346.

Heimpel, G. E. \& J. A. Rosenheim. 1995. Dynamic host feeding by parasitoid Aphytis melinus: the balance between current and future reproduction. Journal of Animal Ecology 64: 153-167.

Heimpel, G. E. \& T. R. Collier. 1996. The evolution of host-feeding behavior in insect parasitoids. Biological Reviews 71: 373-400.

Jácome, I.; M. Aluja \& P. Liedo. 1999. Impact of adult diet on demographic and population parameters of the tropical fruit fly Anastrepha serpentina (Diptera: Tephritidae). Bulletin of Entomological Research 89: 165-175.
Jervis, M. A. \& N. A. C. Kidd. 1986. Host-feeding strategies in hymenopterans parasitoids. Biological Reviews 61: 395-434.

Jervis, M. A.; N. A. C. Kidd \& G. E. Heimpel. 1996. Parasitoid adult feeding behavior and biocontrol - a review. Biocontrol News and Information 17: $1 \mathrm{~N}-22 \mathrm{~N}$.

King, B. 1993. Flight activity in the parasitoid wasp Nasonia vitripennis (Hymenoptera: Pteromalidae). Journal of Insect Behavior 6: 313-321.

Lauzière, I.; G. Pérez-Lachaud \& J. Brodeur. 2000. Effect of female body size and adult feeding on the fecundity and longevity of the parasitoid Cephalonomia stephanoderis Betrem (Hymenoptera: Bethylidae). Annals of the Entomological Society of America 93: 103-109.

Lauzière, I.; G. Pérez-Lachaud \& J. Brodeur. 2001. Importance of nutrition and host availability on oogenesis and oviposition of Cephalonomia stephanoderis Betrem (Hymenoptera: Bethylidae). Bulletin of Entomological Research 91: 185-191.

Leatemia, J. A.; J. E. Laing \& J. E. Corrigan. 1995. Effects of adult nutrition on longevity, fecundity, and offspring sex ratio of Trichogramma minutum Riley (Hymenoptera: Trichogrammatidae). The Canadian Entomologist 127: 245-254.

Leius, K. 1961. Influence of food on fecundity and longevity of adults of Itoplectis conquisitor (Say) (Hymenoptera: Ichneumonidae). The Canadian Entomologist 93: 771-780.

Lewis, W. J.; J. O. Stapel; A. M. Cortesero \& K. Takasu. 1998. Understanding how parasitoids balance food and needs: Importance to biological control. Biological Control 11: 175-183.

Murphy, S. T. \& D. Moore. 1990. Biological control of the coffee berry borer, Hypothenemus hampei (Ferrrari) (Coleoptera: Scolytidae): previous programs and possibilities for the future. Biocontrol News and Information 11: 107-117.

Nurindah; B. W. Cribb \& G. Gord. 1999. Effects of physiological condition and experience on oviposition behavior of Trichogramma australicum Girault (Hymenoptera: Trichogrammatidae) on eggs of Helicoverpa armigera Hubner (Lepidoptera: Noctuidae). Australian Journal of Entomology 38: 104-114.

Quicke, D. L. J. 1997. Parasitic Wasps. Chapman \& Hall, London, 470 p. Quinn, G. P. \& M.,J. Keough. 2002. Experimental Design and Data Analysis for Biologists. Cambridge University Press, London, 557 p.

Quintero, H. C.; A. E. Bustillo; P. Benavides \& B. Chaves. 1998. Evidencias del establecimiento de Cephalonomia stephanoderis y Prorops nasuta (Hymenoptera: Bethylidae) en cafetales del Departamento de Nariño, Colombia. Revista Colombiana de Entomología 24: 141-147.

Scheiner, S. M. 2001. Introduction: theories, hypotheses, and statistics, p. 1-13. In: S. M. Scheiner \& J. Gurevitch (eds.). Design and Analysis of Ecological Experiments. Chapman and Hall, 445 p.

Siekeman, G.; B. Tenhumberg \& M. A. Keller. 2001. Feeding and survival in parasitic wasps: sugar concentration and timing matter. Oikos 95 : 425-430.

Sisterson, M. S. \& A. L. Averill. 2002. Costs and benefits of food foraging for a braconid parasitoid. Journal of Insect Behavior 15: 571-588.

Syme, P. D. 1977. Observations on the longevity and fecundity of Orgilus obscurator (Hymenoptera: Braconidae) and the effects of certain foods on longevity. The Canadian Entomologist 109: 995-1000.

Takasu, K. \& W. J. Lewis. 1995 Importance of adult food sources to host searching of the larval parasitoid, Microplitis croceipes. Biological Control 5: 25-30

Wyatt, T. D. 1997. Methods in studying insect behavior, p. 27-56. In: D. R. Dent \& P. Walton (eds.). Methods in ecological and agricultural entomology. CAB International, $387 \mathrm{p}$.

Zar, J. H. 1996. Biostatistical analysis. Third Edition. New Jersey, PrenticeHall, 662 p. 